\title{
Selected Reference Books of 1988-89
}

\author{
Eileen McIlvaine
}

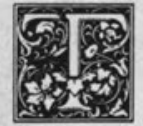

his article follows the pattern set by the semiannual series initiated by the late Constance $\mathrm{M}$. Winchell more than thirty years ago and continued by Eugene P. Sheehy. Since the purpose of the list is to present a selection of recent scholarly and general works of interest to reference workers in university libraries, it does not pretend to be either well balanced or comprehensive. A brief roundup of new editions of standard works is provided at the end of the article. Code numbers (such as AD540, CJ331) have been used to refer to titles in Guide to Reference Books (10th ed., Chicago: American Library Assn., 1986).

\section{BIOGRAPHICAL DICTIONARIES}

Biographisches Lexikon zur Weimarere Republik. Ed. by Wolfgang Benz and Hermann Grame. Munich: C. H. Beck, 1988. 392p. DM 58 (ISBN 3-406-329888). LC 88-163231.

This dictionary contains brief (one- or two-column) biographies of some 500 individuals active in Germany and Austria during the Weimar Republic. Cultural, intellectual, and financial as well as political figures are covered. Thus the reader can find Fritz Lang, Rilke, Krupp, and Freud along with Stresemann and Hitler. The entries conclude with brief bibliographies listing the subject's major works, where appropriate; selected secondary sources; and, if available, locations of personal archives. Most of this information, of course, can be found in other sources, but this one-volume compilation is a useful guide to the personalities of this important period.

A list of ministers in each German government from 1919 through Hitler's 1933 cabinet and a chronology of German political events from 1918 to 1933 are also included. - M.C.

\section{GRANTS}

Directory of International Corporate Giving in America. Ed. by Katherine E. Jankowski, et. al. Washington, D.C.: The Taft Group, 1989. LC sn89-25454.

A welcome new addition to the information sources available to fund-raisers and scholars in search of grant support is this guide to the charitable giving of more than 300 internationally owned American companies. While an extensive literature has long been available on the philanthropy of American-based foundations and corporations, there has been little to date on the activities of foreign corporations, a growing new force on the grant scene as a result of the dramatic shifts in the international economic balance that have taken place in recent years. This new directory, produced by the Taft Group, publisher of

Eileen McIlvaine is Head of Reference, Butler Library, Columbia University, New York, New York 10027. Although it appears under a byline, this column is a project of the reference departments of Columbia University Libraries, and notes are signed with the initials of these individual staff members: Mary Cargill, Beth Juhl, Anita Lowry, Kirk Moll, Robert H. Scott, Sarah Spurgin, Junko Stuveras (Butler Library); Diane Goon and Carrie B. Robinson (Lehman Library); Katherine A. Keller and Barbara Sykes-Austin (Avery Library); James Coen and Diana Sheffield (Business); and Mary Kay and Kathleen M. Kehoe (Science Libraries). 
other guides to American corporate giving, is an important first step toward filling that gap.

The book contains brief profiles of the American giving programs of 245 international corporations operating in this country. Brief data about the headquarters, affiliations, products, size, and revenues of the company is followed by the name and address of the individual to contact about giving programs, information about total giving, the size of the average grant, types of support, geographical preference (if any), giving guidelines, typical grant recipients, leading corporate officers and contributions program officers, application procedures, and other relevant facts, and examples of recent grants. An appendix lists basic information on an additional sixty corporations that have given support to nonprofit organizations in this country but declined to provide more information about their giving program for this directory. Finally, a series of indexes provides a key to companies by headquarters state, operating locations, grant type, nonmonetary support type, recipient type, major products/industry, foreign parent company, and foreign parent country, corporate officers by name, and grant recipients by state.

The noteworthy aspect of the guide is the insight it provides into Japanese corporate giving, a phenomenon heretofore only sketchily described in Englishlanguage literature, but increasingly interesting as Japan's economy moves toward world preeminence. Here, the activities of some 56 Japanese corporate affiliates in this country are touched upon. (For the equally little-known world of Japanese foundation activity, see the brief survey in Japan Council for International Exchange, Japanese Philanthropy and International Cooperation (Tokyo: JCIE, 1985) ).

Thanks to its unique coverage of a new and little-known field, the Directory of International Corporate Giving in America should be an essential addition to any serious collection of guides to corporate and foundation philanthropy.-R.H.S.

\section{RELIGION}

Crumb, Lawrence N. The Oxford Movement and Its Leaders: A Bibliography of Secondary and Lesser Primary Sources. ATLA Bibliography Series, no.24. Metuchen, N.J.: Scarecrow; and London: American Theological Library Association, 1988. 706p. with 3 separate pages of corrections and additions. $\$ 62.50$ (ISBN 0810821419). LC 88-10217.

Lawrence Crumb, with this massive bibliography on the Oxford Movement, has produced a valuable resource detailing the critical literature on one of the most significant developments in nineteenth- and twentieth-century Christianity. It is an important addition to the American Theological Library Association's ATLA Bibliography Series, which has provided the scholarly community with a wide variety of bibliographies on religious topics.

It principally covers materials relating to the early period of the Oxford Movement, 1833-1850, and to its leaders, especially John Keble, Edward Pusey, and John Henry Newman. In the case of Newman (who has a very extensive bibliography) materials are restricted to those dealing with the Anglican period of his life, those "dealing with aspects of his life that were especially important in his Oxford period," " "general studies by recognized Anglican authors," (Pref.) and bibliographic studies. Works by the three leaders published during their lifetimes are excluded, but major posthumous editions are included along with all translations. Appendix Two lists texts, translations, and secondary works on Newman's Apologia pro Vita Sua.

The over 5,400 entries are arranged by year of publication; within each year's section the items are divided into three sequences: books, chapters of books or articles in encyclopedias, and periodical articles. Materials in all formats are listed, including dissertations, manuscripts, and microforms. The bibliography has separate indexes by author (including titles of edited works), periodical title, and subject. The subject index is quite detailed (p.559-706) yet still it suffers from the common problem of bibliographies of this type: there are many subject entries followed only by dozens of entry numbers. This necessitates constant movement back and forth between the index and text. 
While lacking formal annotations, the entries frequently include brief notes that clarify the purpose of the work or provide cross-references with other items in the bibliography (e.g., "reply to no. 464," "rev. of nos. 403, 1016").-K.M.

Foundation for Advanced Biblical Studies. FABS Reference Bible. Defuniak Springs, Fla.: FABS International, 1988. $\$ 795$.

A nonbibliographic CD-ROM available from the Foundation for Advanced Biblical Studies, FABS Reference Bible (FRB) features five different databases containing several translations of the Bible into English and other modern languages; original Hebrew, Greek, and Latin texts of the Old and New Testaments and Apocrypha; grammatically and syntactically analyzed versions of the Greek and Hebrew texts; Greek and Hebrew lexicons; harmonies of the Gospels and historical books of the Old Testament; The Dictionary of the Bible and Religion (Nashville: Abingdon, 1986); an English translation of the works of Josephus, and Lightfoot's collection of works of the early church Fathers.

This collection of texts provides a rich set of tools for biblical study on a single disc, permitting close and comprehensive examination of the original texts, their grammatical structure, and interpretation in a variety of translations along with a variety of lexical, explanatory, and supplementary textual materials. It uses the same FindIT software as REX (see below), and that program's capacity for moving within as well as between texts retrieved by a search is even more useful here. However, learning to use FindIT effectively with FRB is even more difficult than it is in the case of REX: this is clearly not a tool for the casual user. Particularly difficult and even unsettling at first are the special Greek and Hebrew transliteration systems employed and the complex system of symbols used for the grammatical analysis. The reference Bible is, also, by the frank admission of its creators, still partly in a state of development, and its overall quality is therefore far from even. FABS International plans to remove certain "less used" portions of the database in a new, revised edition now in preparation. One can only hope that this measure will not affect the more scholarly materials assembled here, as FRB is a fascinating example of the potential of the optical-disc medium and provides seemingly unique coverage in its field. It is worthy of serious consideration as an addition to the collection of any institution where serious Biblical research is conducted. - R.H.S.

Foundation for Advanced Biblical Studies. $R E X$ (Religious Index). Defuniak Springs, Fla.: FABS International, 1988- . \$895; annual subscription $\$ 695$.

An interesting new arrival on the optical disc scene, REX until recently offered virtually the only indexing in this medium for periodicals on religion. It is a CD-ROM version of Religious and Theological $A b$ stracts (Guide BB43), a publication providing citations and brief abstracts of articles in 200 or so serials, with strongest coverage in the fields of Christianity and Judaism. A subscription provides one new optical disc each year plus four quarterly updates (which can, however, be searched only as text files on a microcomputer hard disk).

Designed for use on IBM XT, AT, or compatible models and a variety of compact-disc players, REX is rather easy to install, but its FindIT software is more difficult to learn at first than is that of most other well-known CD-ROM indexes. Users are presented with a list of indexing terms, and, by use of the directional, backspace, escape, page-up, page-down, and enter keys (as well as by direct input of a desired word), can move throughout the list, selecting individual terms to search or combining them in Boolean statements. The process suffers from certain limitations, however, notably an inability to nest terms in every possible way and a lack of truncation capacity and proximity operators. (It should be noted, though, that Boolean searches are not easy to perform on some other popular CD-ROMs either.) Searching is basically by key word, resulting in a fairly low degree of precision; subject searching is theoretically possible, but is limited to the broad divisional and subject headings used to group 
entries in the printed index and requires a good knowledge of those terms.

The searching process itself is extremely rapid, the number of records found being displayed almost instantly on the lower right-hand corner of the screen. Users then have the option of viewing either a short-title list or individual abstracts one by one. One can move not only up and down the list of found items, but also up and down the parts of the index adjacent to those items, a valuable feature, since articles are grouped in the index under the aforementioned subject headings. Selected records may then either be sent to the printer or downloaded to a disk file.

On the negative side, one must note the absence of any tutorial program, fairly generic documentation, a noticeable number of typographical errors, and less than comprehensive coverage of many subject areas and issues. The recent appearance of the larger Religion Index in CD-ROM represents a serious challenge to REX's monopoly status in the field, and the latter's producers are now expanding the number of journals abstracted in order to provide comparable coverage; it is reported that an additional 75 periodicals will be included in the new version of the disk produced this August. It remains to be seen, moreover, whether the new Religion Index will match REX's retrospective coverage, and REX's provision of abstracting and faster searching speed will continue to be factors to consider.-R.H.S.

\section{LITERATURE}

Hebel, Udo J. Intertextuality, Allusion, and Quotation: An International Bibliography of Critical Studies. Bibliographies and Indexes in World Literature, v.18. New York: Greenwood, [1989]. 175p. \$39.95 (ISBN 0-313-26517-8). LC 88-38862.

This bibliography serves as a welcome guide to the burgeoning literature of "intertextuality," a relatively new but already widespread and influential critical and theoretical concept. In his Preface and Introduction Hebel discusses the development of intertextuality as a critical construct providing new ways of understanding the relations between library texts and the presence of one text in another; intertextuality also encompasses and rejuvenates such traditional areas of study as allusion and quotation. The Introduction consists of a nineteen-page bibliographic essay identifying major currents and seminal works in the scholarship of intertextuality, allusion, and quotation.

The bibliography itself includes over 2,000 citations to articles, books, and dissertations in English and Western European languages published through the end of 1986 ( $a$ few important studies published since 1986 are cited in the Introduction). The Index to Writers and Anonymous Texts enables the user of the bibliography to locate studies focusing on intertextuality, allusion, or quotation in a particular author or work. The Subject Index is a guide to studies of more general topics, such as the "motif of books in books," or on particular genres like poetry, or on other arts, including music and film.-A.L.

Kasack, Wolfgang. Dictionary of Russian Literature Since 1917. Translated by Maria Carlson and Jane T. Hedges. Bibliographic Revision by Rebecca Atack. New York: Columbia Univ. Pr., 1988. 502p. $\$ 40$ (ISBN 0-231-052421). LC 8720838.

This work is an expanded Englishlanguage version of a dictionary first published in German in 1976 and its Supplement 1986 (Lexikon der russischen literatur). Besides updating articles it also adds some 150 new ones. In 619 author and 87 subject entries, it offers a general overview of the field of Russian literature, both Soviet and émigré, since the revolutionary year of 1917. As the author indicates, the first edition of his work was motivated by the lack of any comprehensive Western handbook on the subject, particularly crucial in light of the biases of the eight-volume Soviet Kratkaia literaturnaia entsiklopediia (Guide BD1356). Kasack goes far toward redressing the imbalance, providing coverage of successive generations of émigré writers as well as of dissident or officially forgotten figures within the Soviet Union, while providing treatment of major and a host of 
minor Soviet authors as well. Also somewhat unique and interesting is the handbook's treatment of the system of such topics as official literary prizes, the congresses of the Writer's Union, and the leading Soviet literary periodicals. The dictionary provides no real coverage of literary critics or scholars, nor-with a few exceptions-of non-Russian Soviet writers. The latter omission, while understandable in terms of the need to set some limits, seems particularly regrettable, both because of the broad publication of the works of many non-Russian writers in Russian, and because of the fact that they are not likely to be covered in any other single-volume reference work of this type.

Since the appearance of the German edition, two other important Englishlanguage reference works of comparable scope have appeared: $A$ Handbook of Russian Literature, edited by Victor Terras, (Guide BD1355) and the first eight volumes of The Modern Encyclopedia of Russian and Soviet Literature, edited by Harry B. Weber (Guide BD1358). In Kasack's words, however, both publications "contain considerably fewer authors from the period covered by this dictionary." A sample comparison of coverage of the letter " $B$ " in fact reveals his Dictionary includes about two-and-a-half times as many references to post-Revolutionary writers as Terras's excellent but much broader Handbook. However, less than one-third of $\mathrm{Ka}$ sack's fifty-five " $B$ " entires were lacking in Weber's Encyclopedia, and the latter's " $B$ " section included another thirty-five articles on Soviet Russian authors not mentioned in the Dictionary, along with about ninety entries on Soviet Ukrainian, Byelorussian, and other non-Russian writers. To be sure, the Encyclopedia is only about one-third complete, and has taken about ten years to reach this point. Moreover, Kasack's entries on the secondary figures are generally fuller and more insightful than those in the Encyclopedia, which often appear to be little more than translations of original Soviet encyclopedia sources. In the case of the major figures and literary movements, however, both the Encyclopedia and the Handbook tend to provide much lengthier treatment than Kasack's admittedly well-composed essays.

There appears to be little overlap in the brief bibliographies provided at the end of the articles in all three of the aforementioned works, permitting them to serve as a valuable complement to one another in this respect, as well as others. For its compactness, comprehensiveness, and special focus on the Soviet period, however, it is clear that Kasack's work is the single one most suited to provide ready reference to the broad and complex field of Russian literature during the seven decades of Soviet rule.-R.H.S.

\section{A Bibliographical Guide to Spanish-American} Literature: Twentieth-Century Sources. Comp. by Walter Rela. Bibliographies and Indexes in World Literature, v.13. New York: Greenwood, 1988. 381p. $\$ 49.95$ (ISBN 0313258619). LC 88-15443.

This annotated bibliography lists selected works published or reprinted since 1945 on the literatures of fourteen Spanish American countries (Argentina, Bolivia, Chile, Colombia, Costa Rica, Cuba, Dominican Republica, Ecuador, Mexico, Panama, Peru, Puerto Rico, Uruguay and Venezuela), from the colonial times to the present.

The work is divided into four major parts: bibliographies, dictionaries, history and criticism, and anthologies. Under each category, the materials are arranged by genre within a country section: poetry, prose, fiction, drama, and essay. The bibliography provides a name index, which includes both authors as subjects and authors of cited work, but there is no topical or geographical index. It would be hard to retrieve any studies by theme, regardless of the country of origin or across genres. The very traditional arrangement by country, genre, and format of publication limits the usefulness of the bibliography.

The section on Anthologies occupies over one-third of the bibliography, listing collections in Spanish and English. Notes often indicate which authors are included in an anthology and the names are indexed in the Author Index. In other parts of the Bibliography, the contents of the proceedings of a congress is similarly ana- 
lyzed and indexed by author. This feature should be useful for identifying conference papers and short stories in anthologies.-J.S.

\section{ENGLISH LITERATURE}

Ringler, William A., Jr. Bibliography and Index of English Verse Printed 1476-1558. London: Mansell, 1988. 440p. $\$ 160$ (ISBN 0-7201-1892-1). LC 88-8517.

This is the first installment of a project to extend Brown and Robbins's Index of Middle English Verse (Guide BD637) through the Tudor period. Later volumes have been planned to extend the index of printed verse through 1700 , and to provide indexes and bibliographies of manuscript texts. Because the compiler died while this volume was in production, it is hoped that these projected volumes may also reach publication.

This volume is organized into two main sections: verse printed $1476-1500$, and verse printed 1501-1558. Each of these sections includes a bibliography and a first line index.

Entries in the bibliographies include the main entry and STC number, author and title exactly as they appear on the title page, headings or colophons, place of publication, library copy used, reprints and facsimiles, number of poems in the volume and complete number of lines, and a cross-reference to the first-line index.

Entries in the first-line indexes include authors, titles, and dates of attribution, dates of composition, total number of lines, verse forms, STC numbers of editions containing the poem, inclusive dates of editions, signatures or folios on which the poem appears in the first edition, and genre and subject classifications.

The subject and author indexes at the back of the volume include lists of verse by refrain, verse form, English poet, translated author, literary form and genre, title, historical person and event, and religion.

This volume represents a tremendous contribution to English literary scholarship; readers will now be able to locate the verse of many of these authors in minutes rather than years. It is recommended to all libraries with strong collections in English literature.-S.S.

Schlueter, Paul. An Encyclopedia of British Women Writers. Garland Reference Library in the Humanities, v.818. New York: Garland, 1988. 516p. $\$ 75$ (ISBN 0824084497). LC 88-21393.

This bio-bibliography provides entries for 370 British women writing from the Middle Ages to the present. English, Scots, Welsh, and Irish authors are included, as well as those from Commonwealth countries who have lived a significant portion of their lives in Great Britain.

The format is based on that of American Women Writers (Guide BD412). Signed entries provide basic biographical facts, an essay ranging from one to two pages, a list of works, a brief bibliography of secondary materials, and a list of reference books (e.g., DNB, CA, DLB) where additional information may be found. The essays are well written, and the bibliographies of secondary materials list many recent works, though citations to articles give only the journal title and year. The Index includes names and pseudonyms, professions of writers, subjects treated in the works, and literary forms and genres. There are no chronological or geographical indexes.

Although it is possible to find much of this information in a variety of other sources, An Encyclopedia of British Women Writers brings essential information about these writers together in a single, informative volume. Recommended for libraries of all sizes.-S.S.

Spector, Robert Donald. Backgrounds to Restoration and Eighteenth-Century English Literature: An Annotated Bibliographical Guide to Modern Scholarship. Bibliographies and Indexes in World Literature, v.17. New York: Greenwood, 1989. 553p. \$59.95 (ISBN 0-31324098-1). LC 88-32807.

Intended as a guide for the student of eighteenth-century literature, this bibliography is broadly interdisciplinary in its coverage of the political, economic, social, and cultural history of Britain during the eighteenth century. Thus it is of interest to students and scholars not only of litera- 
ture, but also of history and related disciplines. It includes books and articles in English that constitute "significant scholarship that will be interesting for both the specialist and serious student" (p.viii). The annotations are descriptive and, in some cases, evaluative.

The bibliography is arranged according to general disciplinary or topical categories: bibliographies; publishing, printing, and journalism; history and politics; religion; philosophy; science, medicine, and technology; economics; crime and the law; society, manners, customs, and attitudes; education and scholarship; language and rhetoric; literature and the arts. Some categories have topical subcategories. Because there is no subject index, users looking for references on a narrower subject will have to scan through the appropriate section(s). There is, however, an author index. $-A$.L.

\section{DRAMA}

Peterson, Bernard L. Contemporary Black American Playwrights and Their Plays: $A$ Biographical Directory and Dramatic Index. New York: Greenwood, 1988. 625p. \$75 (ISBN 0-313-25190-8). LC 87-17814.

This is a directory of approximately 700 black American dramatists (including radio and television screenwriters) who have been writing since 1950 . The author has included all available biographical information, verified whenever possible with the playwrights themselves; a complete list of plays and/or scripts with brief plot summaries and production histories; and bibliographic information for published works.

Among the useful appendixes is a list of unpublished plays, arranged by author, located in the Schomberg Collection of the New York Public Library and other repositories. The author also lists anthologies which include one or more plays by black playwrights, a useful updating of a similar list in James Hatch's Black Playwrights, 1823-1977 (Guide BD482); a list of reference and critical sources; and a list of dissertations on contemporary black American theater. There is an index by play title, including those listed in the appendixes, and a general index.

Despite its cost, any public or academic library needing sources on black writers or contemporary theater will welcome this book.-M.C.

\section{ART AND ARCHITECTURE}

Bibliography of American Folk Art for the Year 1987. New York: Museum of American Folk Art, [1989]. 32p.

Eugene Sheehy and Rita Keckiessen, distinguished compilers of the Guide to Reference Books, have turned their attention to another area, one poorly covered by bibliographies. Sponsored and produced by the Museum of American Folk Art in New York, the Bibliography of American Folk Art is based upon their library. It limits itself to the North American area north of Mexico and includes books, pamphlets, and exhibition and auction catalogs published in 1987. The arrangement is topical with general headings listed first, e.g., folk art of ethnic groups, followed by genres, e.g., gravestones and cemeteries or naive/non-traditional art. The volume concludes with a good author, title, and subject index. We look forward to the next volume.-E.M.

Diamonstein, Barbaralee. The Landmarks of New York. New York: Abrams, 1988. 416p. \$45 (ISBN 0-8109-1270-8). LC 883317.

What makes a "landmark" a landmark? The twelve-page introduction to this book provides the definition according to the New York City Landmarks Preservation Commission. The history and composition of the commission and the designation process are also included.

As the title suggests, this work includes all landmarked structures in New York City as the end of January 1988. The buildings are arranged in order by date and each entry includes black-and-white photographs, dates, address, name of architect (where known) and the date of designation.

The entries themselves vary in the type and quality of material presented. The text was based in part on the designation re- 
ports of the Landmarks Preservation Commission. Anecdotal and historical material was solicited from property owners, city officials, historical societies, architects, preservationists, and citizens. An entry provides a brief indication of the history and significance of each designated property.

Included at the end of this volume is a section on historic districts of New York. Each district includes a map and the date of designation. Content is similar to that found for individual structures. A list of scenic and interior landmarks follows which only includes the building name. A section entitled, "Sites Heard by the New York City Landmarks Preservation Commission But Not Designated 1982-January 1988," includes building name, address, and date of hearing. Landmarks and historic districts that were designated between February 1 and July 12, 1988 are marked with an asterisk. Finally, an index lists landmarks and includes categorical entries, i.e., apartment houses, bridges, and churches.

This work updates the 1979 pamphlet, $A$ Guide to New York City Landmarks, published by the New York City Landmarks Preservation Commission. While Landmarks of New York provides an important resource as an index and photographic guide, it lacks a bibliography and the landmark designation report numbers. These two elements would greatly enhance the use of this work for research purposes.K.A.K.

\section{Index to Historic Preservation Periodicals.} General editor, Hye Yun Choe. National Trust for Historic Preservation Library of the University of Maryland, College Park. Boston: G.K. Hall, 1988. 354p. \$95 (ISBN 0-8161-0474-3).

Construction Index. Chicago: ArchiText, 1987- . Quarterly. \$75 1989 subscription; \$50/ea. 1987 and 1988 annual compilations (ISSN 0892-2047).

Australian Architectural Periodicals Index: AAPI. Compiled by the staff of the Reference Dept., Stanton Library. North Sydney, NSW Australia: Stanton Library, 1986- . Microfiche. (ISSN 08172684).
Three periodical indexes for consideration in architecture collections have recently been published. Each concentrates on a very specific segment of the literature already covered by the more comprehensive Avery Index to Architectural Periodicals (Guide BE253) and the Architectural Periodicals Index, published by the Royal Institute of British Architects (BE257), but includes some journal titles or document types outside their scope.

The Index to Historic Preservation Periodicals, produced by the staff of the National Trust for Historic Preservation Library, now at the University of Maryland at College Park, is a compilation of periodical articles from approximately 325 popular and scholarly serials and historic preservation organization publications, as well as pamphlets, newspaper clippings, and brochures treating all aspects of historic preservation. "The result has been a unique current-awareness tool for preservationists and a finding aid to the periodical and vertical file collections of the National Trust Library"' (Introd.).

The present volume, covering the period from 1979 to 1987 , contains over 6,000 entries of merged catalog cards covering topics in architecture, law, historical research, design review, interior treatments for historic buildings, restoration, real estate, fund-raising, statewide historic preservation programs and federal policy. Access is by subject only, with a single subject heading assigned to each citation. Multiple searches are therefore necessary in order to research a topic adequately. The library staff continues to collect and index material for dissemination to $\mathrm{Na}$ tional Trust members and staff. Requests for this updated information can be obtained by mail or telephone from the $\mathrm{Na}$ tional Trust Library.

For technical architectural literature the Construction Index covers 33 Englishlanguage journals selected by the editor for their potential usefulness to practicing professionals, with emphasis on building design and construction. Arrangement of the contents is organized by a 5-digit numerical classification structure based on the CSI Masterformat-Master List of Section Titles and Numbers, published by the 
Construction Specifications Institute, a system also used for product and materials classification in Sweet's Catalog File, and therefore familiar to most practitioners. Access is consequently by broad subject category, such as safety and protection, building types, concrete, doors and windows, electrical, handicapped construction, etc. Articles are annotated and arranged within each section alphabetically by journal title. Issued quarterly, the fourth-quarter issue is cumulative for the year. Photocopies of articles from approximately three-quarters of the journals indexed are available from the publisher, ArchiText.

Finally, the architecture of a single region is covered in-depth by the Australian Architectural Periodicals Index "in response to a need for effective access to Australian and New Zealand architecture journals. . .. Emphasis is on architecture and building in Australia and New Zealand, but overseas projects, designs, etc., have been included, where there has been some demand" (Introd.).

The index is a product of the reference department of the Stanton Library, which began developing a handwritten card file in 1976. Now available on microfiche, the AAPI evolved from an early finding list into an index of 20,000 entries covering periodical articles from 45 journals for the period from 1910 to 1983 . Subjects include architecture and other aspects of the built environment, conservation and restoration, landscape architecture, and planning. Biographical information, particularly for early twentieth-century architects, can be found under architect or firm name; otherwise access is by building type or general subject heading, with specific building names used "very occasionally, if the subject has been popular." There is no name authority, so all variations of individual or corporate names need to be searched.

For large general libraries or those with moderately-sized architecture collections, the coverage of the two major architectural indexes should be sufficient to access the most important articles and books on historic preservation, regional architecture, or architectural aspects of the build- ing and construction trades. For comprehensive collections, each of these works can lead to useful sources of information outside the previously existing guides to the literature.-B.S. $-A$.

\section{STATISTICS}

Thorndale, William and William Dollarhide. Map Guide to the U.S. Federal Censuses, 1790-1920. Baltimore: Genealogical Publishing, [1987]. 420p. \$49.95 (ISBN 0-8063-1188-6). LC 87-80193.

This atlas is a fascinating source for the historian, genealogist, demographer, or geographer. It contains state maps showing contemporary county boundaries for each federal census year, beginning with 1790 and ending with 1920 "in anticipation of the release of the name lists of that [manuscript] census in 1992" (Pref.). Some maps are also included from various state censuses taken in intervening years (e.g., Minnesota in 1857), if those records were received by the Census Bureau in Washington.

The Map Guide is intended as an aid to researchers working with the manuscript census, the actual house-to-house enumeration of individual heads of households and their families and dependents, which is organized at a county level. Its 393 black-and-white maps depict county boundaries at the time of a particular census, superimposed over modern county lines. Availability of manuscript returns for various counties is indicated on each map. Detailed explanatory notes describe border disputes, settlement patterns, and name changes.

Though these maps are primarily for use with the census, they also provide information about population shifts, political and economic change, and even foreign relations-viz. an 1840 map of Texas which explains the depopulation of most border counties due to "threat of invasion from Mexico." The authors, in a helpful preface and introduction, outline federal and state boundary laws, describe federal census-taking methods in the nineteenth century, and discuss the preservation and loss of federal and local archives. They also warn of the unreliability of some cen- 
sus materials, whether because of copy errors or undercounts. An appendix describes the "pitfalls of mapping boundaries," and a bibliography lists federal, state, and county sources. The Index lists both present day and defunct or renamed counties.

The maps included here are intended to represent only political divisions, and only a few geographical features, other than rivers and large lakes, are depicted. The inclusion of major cities and more topographical detail would have been helpful. However, the authors have provided a graphic point of reference for works such as Joseph Nathan Kane's American Counties (Guide CL204), and have brought together in one handy volume material otherwise embedded in innumerable local and county histories.-B.J.

\section{ARMS CONTROL}

Arms Control, Disarmament and International Security: An Annual Bibliography, 1987- . Claremont, Calif.: Regina Books, [1988]- . \$29.95 (ISSN 08996547). LC sn88-2108.

This annual bibliography is sponsored by the Center for the Study of Armament and Disarmament, California State University, Los Angeles, and the Arms Control Association, Washington, D.C., under Richard D. Burns as editor-in-chief.

Its focus is English-language books and monographs, articles, pamphlets, governmental and non-governmental documents, dissertations, and reference works. The 2,016 citations are arranged in a detailed classed arrangement based on that used in Richard D. Burns' Arms Control and Disarmament: A Bibliography (Guide CJ610). The eight topical chapters cover arms control negotiations, proposals and treaties; arms control/disarmament special issues; military strategy and theory; armed services and weapon systems; defense spending and procurement; international and regional security; civil nuclear power; peace education, movements and research; a final chapter lists reference works (including annuals and journals). There are personal author and subject indexes.
The Arms Control Association's monthly Arms Control Today has always been especially valued because of its bibliographical feature "Arms Control in Print"; having all the 1987 citations in a cumulative annual volume with indexing is undeniably useful, and many new citations have been added to this volume. The great majority of the citations will be readily accessible in most college and university libraries. The subject indexing is not as satisfactory as it could be; the user is first advised to see the extended table of contents, since its entries are not repeated in the subject index. There is no country category for the United States or the Soviet Union, as there is for other countries; instead, entries are under the armed forces, e.g., Army, Soviet or Army, U.S. There are no cross-references or see-also references alerting the user that the $\mathrm{Na}$ tional Security Council entries are filed under NSC, or the Central Intelligence Agency under CIA. One page of the index has been printed twice, and there are annoying typographical errors. True, the table of contents is very detailed, but a good subject index would greatly improve the next edition of this work.-D.K.G.

Atkins, Stephen E. Arms Control and Disarmament, Defense and Military, International Security, and Peace: An Annotated Guide to Sources, 1980-1987. Santa Barbara: ABC-Clio, [1989]. 411p. $\$ 37.50$ (ISBN 0-87436-488-4). LC 88-21822.

Stephen E. Atkins is the arms control bibliographer for the arms control collection at the University of Illinois, UrbanaChampaign. Since 1981, the collection has provided research support for the Arms Control, Disarmament and International Security Office, an interdisciplinary research organization located at the university and founded in 1978. Atkins has focused on publications from 1980 through mid-1987 because of that period's transition between the Carter and Reagan administrations, and the Reagan administration's changes in defense and security policies.

The scope of the bibliography encompasses primarily English-language materials (with some French, German, and 
Spanish titles) of the following types: annuals and yearbooks; bibliographies; databooks, handbooks, and sourcebooks; dictionaries; digests; directories; encyclopedias; guidebooks; hearings; journals; microfilm collections; newsletters; papers from strategic institutes and think tanks; slide programs; strategic atlases; textbooks; and monographs. The four main subject chapters (arms control and disarmament, defense and military, international security, and peace) are subdivided by these formats. Each of the 1,596 citations consists of publishing information (including prices for serials) and a threeor four-sentence critical abstract. There are subject and author/title indexes (corporate authors are not included), and a publishers' directory.

Atkins' annotations are excellent. He points out the chief value of each work, whether it be its currency, the reputation of its author, its statistics, etc. While most of his comments are positive, e.g., "the indispensable bibliography in the field," "the standard annual," "the best source available," "unrivaled," he can also be astringent: the U.S. Dept. of Defense's Soviet Military Power is criticized because of "some overblown rhetoric," and the annotation for Laird M. Wilcox's Bibliography on Espionage and Intelligence Operations notes "The compiler makes no pretense about his right-wing orientation, and the annotations reflect his viewpoint. This bibliography is highly suspect and should be used with caution."

Reference librarians and collection development librarians will be grateful to Akins for this work, and to ABC-Clio for pricing it so reasonably. Every college and university library should purchase this excellent and reliable bibliography, and use it heavily for reference, bibliographic instruction, and collection development.D.K.G.

\section{WOMEN}

The Black Women Oral History Project: Guide to the Transcripts. Ed. by Ruth Edmonds Hill and Patricia Miller King. A project sponsored by Arthur and Elizabeth Schlesinger Library on the History of
Women in America. Cambridge, Mass.: Radcliffe College, [1987]. 152p.

The Black Women Oral History Project was begun by the Schlesinger Library of Radcliffe College in the mid-1970s. "The goal of the project was to interview a cross-section of the many women of African descent who made significant contributions of varying kinds to American society in the early and mid-decades of the twentieth century" (Pref.). Seventy-two women from all over the United States were interviewed, many of whom were prominent in the fields of education, social work, politics, medicine, law, or the arts. Topics explored in the interviews include family life and background, education, employment, voluntary activities, and personal life.

Each entry in this guide provides a brief biography of the interviewee, a summary of the primary subjects covered in the transcript of her oral history, and information on access to the transcript and interview tapes. The index combines names and subjects mentioned in each entry. Although access to some of the transcripts and tapes is temporarily restricted, most may be read at the Schlesinger Library, or may be borrowed through interlibrary loan. Copies of the transcripts may also be acquired by manuscript and oral history repositories for the cost of the photocopying.-S.S.

Women's Movements of the World: An International Directory and Reference Guide. Ed. by Sally Shreir. London: Longman, [1988]. 384p. \$95 (ISBN 0-582-00988-X). LC 87-35031.

Described by the editor as "a guide to the current status of women's issues and organizations," this Keesing's publication attempts to identify and describe women's liberation movements in a global context. The work, organized primarily by country of interest and origin, also contains a section on "international organizations," organizations whose scope and domain cross national and, sometimes, regional boundary lines. Lastly, there is a bibliography which contains a sample of the published material-books and journals-of selected organizations. 
Each national entry has an introductory section, broadly covering the current socio-politico-economic status of women within the given country, and includes such variables as: women's participation in political life, the workforce, and education; women's rights within marriage and divorce; and laws and practices relating to birth control and abortion. The next section is a list of the nationally recognized women's organizations as well as a sample of lesser-known groups, listed alphabetically in the language of the country of origin. International organizations, however, are listed alphabetically in the English-language versions of their names. The arrangement of the bibliography, which purports to be a selection of "publications of general interest" published by women's organizations, is divided into periodicals and book sections. The bibliography also includes some publications, though not published by women groups, that are of "particular scholarly relevance."

The emphasis in the compilation of the directory appears to be on organizations "with a separate and distinct membership," although there are a number of organizations engaged in areas whose membership is indistinguishable from a professional staff, e.g., in the areas of research and education, database and library services, and technical assistance to women in developing countries. Not surprisingly then, inclusion is broad, not simply reflecting women's organizations "united by common beliefs and attitudes," e.g., Union des Femmes Burundaises (Union of Burundi Women) and the Council of Women's Associations of Burma, but also organizations of women with common activities, e.g., Tentele Women's Co-operative Society of Swaziland or Association for Women in Development of the United States, as well as women with common vocations that may highlight the significance of the position of women in a community, both national and global, e.g., organizations of women doctors and lawyers.

Unfortunately there is no index. Perhaps the editor assumed that the arrangement by country would be sufficient ac- cess. An index would have proven useful to those users who might remember the name of an organization but not the country of origin; the assumption being that the user should not have to refer to another source for access. The bibliography seems useful though an expanded version that would include more Third World publishers would be of greater value.

In arranging the national organizations by language of the country of origin, the editor displays an unquestioned sensitivity to the subject matter, but in arranging the international organizations by the English-language version of their name only, she seems to lack the same insight. One would assume that she would also arrange these by the language of the country of origin, perhaps with an English translation.

Despite its flaws, the work is still useful both in what it attempts to do and what it accomplishes. Directory information for some of the lesser-known organizations appear here, and nowhere else. Hopefully, in its next edition, the editor will continue to improve the volume as it is a very useful work for scholars and other interested readers. In the interium, however, the work does provide, in one place, a necessary resource of information on a movement that continues to gain momentum throughout the world.-C.B.R.

\section{BUSINESS}

International Directory of Company Histories.

Ed. by Thomas Derdak. Chicago: St. James, 1988. v.1. \$95 (ISBN 0912289104).

This directory, the first of a projected five-volume set, outlines the historical development of "the world's largest and most influential companies" (Pref.). Criteria for company selection include one or both of the following: (1) a minimum of \$2 billion (U.S. dollars) in sales and/or (2) a leading influence in its industry or in a geographic area. The five-volume set will include 1,250 companies with each volume containing 250 entries. Volume one covers ten industries ranging from advertising to drugs; volumes two through five will cover industries from electronics to utilities. 
The entries are prefaced by a profile showing company logo, legal name, address, and telephone number of headquarters, public or private status, incorporation date, number of employees, market value and amount of sales, and the stock market on which it is traded. End-notes list principal subsidiaries, and citations to further readings on both the company and the industry. Wholly-owned subsidiaries are listed as separate entries.

The chapters are arranged alphabetically by company within each industry. The text, averaging from two to five pages for each company, is enlivened by journalistic characterizations of the personalities that shaped the company. There is a handy list of companies grouped within their industry categories and an index to companies and persons.

The directory is a valuable resource. In offering a guide in summary form to the elusive tidbits of information that paint a portrait of a corporation, it fills an important void left by traditional company directories. - D.S.

Strauss, Diane Wheeler. Handbook of Business Information: A Guide for Librarians, Students, and Researchers. Englewood, Colo: Libraries Unlimited, 1988. 537p. $\$ 37.50$ (ISBN 0872876071). LC 88-23093.

This handbook is designed to introduce the user to the basic concepts and vocabulary of business, while providing detailed descriptions of key data sources. The first eight chapters are devoted to formatspecific sources, e.g., guides, bibliographies, looseleaf sources, directories, etc., and the remaining ten chapters are individually concerned with particular fields of business such as money, investment, banking, marketing, and accounting.

Each of the latter group of chapters begins with a discussion of the fundamentals of its topic, and this is followed by considerations, in a narratively amplified istyle, of the significant reference tools. Illustrations of sample entries from sources are provided with a practical generosity.

Inclusiveness is intentionally absent from this handbook; the field of management literature, for example, is omitted. It was decided that areas of business cov- ered adequately elsewhere could be left out in favor of a gain in the thoroughness of treatment of those included. Twelve appendices list items, sources, and agencies of a particularly useful nature, especially to a beginning librarian or researcher.

Machine-readable data files (MRDF) are given a chapter unto themselves. The nature of the industry providing these sources will cause the information to become dated more quickly than that related to the print-based sources. In implicit recognition of this fact the print sources that track and monitor MRDF products are described.-J.C.

\section{ARCHAEOLOGY}

Past Worlds: The Times Atlas of Archaeology. Maplewood, N.J.: Hammond, 1988. 319p. $\$ 85$ (ISBN 0-7230-0306-8). LC 88675201.

More of a pictorial encyclopedia than a simple atlas, Past Worlds depicts in maps, graphs, charts, photographs, and drawings "world history, from the beginning of human life down to the emergence of the modern world" (Introd.). As no atlas could possibly cover such a broad time span comprehensively, the authors have chosen to highlight key sites, cultures, and topics and have managed to convey a great deal of information in a handsomely illustrated volume.

Maps are grouped within five broad chronological and geographical chapters, from "Human Origins, 16 Million-10,000 B.C.," to "Towards the Modern World, A.D. $650-1800$." An introductory chapter covers techniques in archaeology, such as dating and excavation, and topics such as warfare, burial, and ritual. Each two-page spread is devoted to one map subject, with descriptive text, and photographs or illustrations of cultural artifacts, costumes, building elevations, floor plans, cross-sections, or graphs. A useful chronology, divided into five geographic regions, lists significant events, sites, and cultures. A glossary of archaeological terms, an index, and a short bibliography for each map complete the atlas.

The topical nature of this volume will please many readers, who will find here a 
visually appealing thumbnail sketch of the Mississippi Mound Builders or the Aztecs or the Indus Valley Civilization. One wishes that entries in the index might be somehow "weighted" to indicate which topics are the subject of a two-page spread and which are only spots on a map or mentioned briefly in the text. However, readers of all ages will enjoy browsing through this colorful volume.-B.J.

\section{HISTORY}

The Blackwell Dictionary of Historians. Ed. by John Cannon and others. Oxford, New York: Blackwell, 1988. 480p. \$45 (ISBN 063114708X). LC 88-19361.

The dictionary of historians and historiography covers the period from antiquity to the twentieth century. Concise articles, largely contributed by British historians, give biographies of some 450 historians, from Thucydides to Arthur M. Schlesinger, Jr. Over 50 living scholars are included. The work is compiled for British and American readers (see the Preface) and consequently selections favor AngloAmerican historians and their principal sources of inspiration, Greco-Roman authors, and Western European historians. Other areas of the world are very skimpily dealt with by survey articles: "Japanese historiography," "New Zealand historiography," etc.

Each signed entry is accompanied by a short bibliography: main publications of the biographee and further readings on the subject. In addition to biographies of historians and brief histories of historiography by country or region, the Dictionary includes such topics as genres of history ("legal history," "'oral history"), schools and theories ("Whig interpretation of history," "Annales school") and interdisciplinary approaches ("cliometrics," "anthropology and history").

Within its limitations, the dictionary is a good one and even a readable, entertaining piece of work to peruse.-J.S.

Lincove, David A. and Gary R. Treedway. The Anglo-American Relationship: An Annotated Bibliography of Scholarship, 1945-1985. Bibliographies and Indexes in World History, v.14. New York: Greenwood, 1988. 415p. \$49.95 (ISBN 0-313-25854-6). LC 88-7225.

From now on the "special relationship" between England and the United States will be much easier to document, thanks to this well-arranged bibliography. The authors have included monographs, essays, articles, and British and American dissertations discussing the relations between the two countries from the end of the Revolutionary War through the 1970s.

The first part covers non-diplomatic relations, including social, cultural, and economic relations arranged by topic. Pure literary criticism is not included. The reader, for example, can find discussions of Charles Dickens' views of slavery and the American reaction, but not articles specifically on Martin Chuzzelwit. The second part covers diplomatic and military relations, and is arranged chronologically. An author and a detailed subject index conclude this useful bibliography.-M.C.

Moir, Martin. A General Guide to the India Office Records. London: British Library, 1988. 331p. (ISBN 0712306293).

Singh, Amar Kaur Jasbir. A Guide to Source Materials in the India Office Library and Records for the History of Tibet, Sikkim and Bhutan, 1765-1950. London: British Library, 1988. 187p. $£ 30$ (ISBN 071230634X).

The British Library has published these two volumes describing various parts of the collection of the India Office Library. Formerly the East India Company, the archives and books passed through a succession of departments of the British government, including the Foreign and Commonwealth Office, to become a part of the British Library in 1982. Though the Library was carefully cataloged and maintained, researchers found little help in determining exactly what materials are in this exceedingly rich collection. There was a Guide to the India Office Records $1600-1858$, by William Foster (London, $1919.130 \mathrm{p}$.) and there have been guides to portions of the collection, especially the books. S. C. Sutton issued a Guide to the India Office Library, 2d. ed., 1967 (Guide DE98) which was not very detailed. 
Martin Moir's General Guide to the India Office Records first describes the administrative organization with charts, descriptions of duties, sub-units, and details of appointment. This helps one in understanding the organization of the archives, which is carefully described in the second part. Each class and file is detailed and cross-references to parts of a file in another record group are cited. Mr. Moir does state that for the early period Foster is still useful and cites specific page numbers in it.

Amar Kaur Jasbir Singh covers specific countries: Tibet, Sikkim, Bhutan for official and private papers but also for maps, official publications, prints and drawings, and books. Singh is much more specific in giving the researcher the name of a paper with its file number, but then he has fewer papers to identify than Moir. Both volumes are well indexed.

Any collection serving researchers on South Asia will find these two volumes essential.-E.M.

Valk, Barbara G., et al. BorderLine: A Bibliography of the United States-Mexico Borderlands. Los Angeles: UCLA Latin American Center Publications; Riverside: University of California Consortium on Mexico and the United States, [1988]. 711p. \$150 (ISBN 0-87903-112-3). LC 88-4565.

BorderLine is a printed by-product of the Borderline database, a subsystem of the ORION online catalog at UCLA and available for searching to all those who have access to the UCLA OPAC. While the database itself is still growing, the "need to disseminate the research as widely as possible... prompted the publication of the citations compiled to date" (Pref.). Researchers are invited to request updates on specific topics from the UCLA Latin American Center.

Similar in scope to Ellwyn Stoddard's Borderlands Sourcebook (Guide DB129), this bibliography covers all aspects of Southwestern culture, sociology, history, demography, politics, religion, and geography. The borderlands are here defined as four U.S. states: California, Arizona, New Mexico, and Texas and six Mexican ones:
Baja California, Chichuahua, Coahuila, Nuevo Leon, Sonora, and Tamaulipas. Material in all formats is included: books, serials, journal articles, technical reports, government documents, dissertations, maps and conference proceedings. "Citations were selected on the basis of their research value and pertinence to the study of the border region and border issues" (Intro.). The majority of entries were published between 1960 and 1985, though important earlier works, such as Paul Horgan's Great River, are also included, as well as many old books and maps reprinted in the last few decades.

Entries are in a classified arrangement within twenty-six chapters, which cover subject areas such as labor, immigration, anthropology, agriculture, and description and travel. Unfortunately, there is no subject index, so readers are forced to rely on a detailed table of contents which describes the scope and focus of each chapter. Chapters are further subdivided into geographical, time period, or format (bibliographies, maps) sections. An author index concludes the volume. Locations, drawn from the holdings of about 35 regional libraries, are indicated for each item.-B.J.

\section{SCIENCES}

Encyclopedia of Astronomy and Astrophysics.

Ed. by Robert A. Meyers. New York:

Academic, 1989 . 807p. $\$ 49.95$ (ISBN 0-

12-226690-0). LC 88-24062.

This encyclopedia is derived from the Encyclopedia of Physical Science and Technology, a 15-volume set published by Academic Press in 1987. This fact is stated in extremely small print on the verso of the title page, though it appears nowhere in the preface or introduction of the book. It consists of 41 signed survey articles on broad topics such as infrared astronomy, quasars, black holes, and planetary atmospheres. Each article is prefaced by a glossary defining key terms, and by a brief outline of the article's structure. Articles typically contain many useful illustrations and charts, and each has an appended brief bibliography. These bibliographies are uneven in that some consist of refer- 
ences to technical journal articles while others list references to books and articles intended for the general reader. The authors include some well-known names, notably Stuart Shapiro and Harry Shipman. The articles are solid expositions of technical topics written by specialists who do not hesitate to use mathematical and chemical equations to express their ideas, although the reader is spared the derivations of these equations. A new article on Supernova 1987A seems to be the only revision of the 1987 parent publication. An index is included, but it is not sufficiently detailed to include glossary terms.

This volume is an interesting survey of current astronomy and astrophysics topics, and a good purchase for the library unable to afford the parent publication. It is the newest such publication available for a fast-moving field. However, as a reference volume it has its drawbacks. Reference questions on such topics as parallax and syzygies cannot be easily answered using this volume due to the insufficiently detailed index. Material on instrumentation is not grouped together. Instead the volume offers articles on radio and optical astronomy, but x-ray and gamma-ray instrumentation must be accessed through the index. The undergraduate seeking an article about the planet Venus will be disappointed in this volume, since it does not contain discrete treatments of individual planets. In short, this volume will be a good addition to a college reference collection or to a private library, but unfortunately it will not replace older volumes such as the Larousse Encyclopedia of Astronomy or the Mc-Graw Hill Encyclopedia of Astronomy. - M.K.

Singleton, Paul and Diana Salsbury. Dictionary of Microbiology and Molecular Biology. 2nd ed. Chichester, New York: John Wiley, 1987. 1,019p. \$149 (ISBN 0471-91114-3). LC 87-19047.

This is a thoroughly revised and expanded edition of the Dictionary of Microbiology (Guide EC31). The scope and length of the original work has doubled. The authors' aim was to "assemble a detailed, comprehensive, and interlinked body of information ranging from the classical de- scriptive aspects of microbiology to current developments in related areas of bioenergetics, biochemistry and molecular biology" (Pref.). They have achieved this goal by producing a dictionary which provides much more than simple definitions. It contains a great deal of background information on the concepts and research issues in microbiology, biochemistry, bioenergetics and molecular biology.

The dictionary includes definitions of salient techniques, terms, acronyms and concepts, and descriptions of over 1,000 microorganisms. The original entries have been updated and entries have been added. Because the alphabetical order of the entries is complex, following biochemical conventions, there is a guide to this alphabetic scheme to aid students in its use. The authors have provided five appendices which contain flow charts illustrating biochemical pathways, as well as a key to journal abbreviations, and a key to book references. $-K . M . K$.

\section{NEW EDITIONS, SUPPLEMENTS, ETC.}

Maps Contained in the Publications of the American Bibliography 1639-1819: An Index and Checklist (Metuchen, N.J., Scarecrow, 1988. 367p. $\$ 37.50$ ) by Jim Walsh is an index to all maps in books or maps separately published which are cited in Evans (Guide AA557) or Shaw and Shoemaker (Guide AA567). The entries are arranged by American Bibliography number and there are indexes by date of publication, place of publication, name, book title, map title, and geographic area.

Only those works in Arabic, Persian, and Ottoman and modern romanized Turkish cataloged by the Library of Congress were included in the National Union Catalogs (Guide AA126) but publications in those languages have been reported by some $\mathbf{2 4 0}$ libraries in the United States. Now the Library of Congress has published volume 1 of The Near East National Union List, compiled by Dorothy Stehle (Washington, D.C., 1988. 867p. \$47). This includes the main entries beginning with $A$ and all the cross-references to them, B-Z. A title index refers the user to the 
proper main entry; cut-off date was 1979.

The new second edition of the Oxford English Dictionary has appeared (Oxford, Clarendon Pr.; N.Y., Oxford Univ. Pr., 1989. 20v. $\$ 2,500)$. On first glance it seems the entries from the first edition and from the Supplement (Guide AD27) have been merged with small changes. About 5,000 new words, senses, and combinations have been added primarily in the first part of the alphabet because the first two volumes of the supplement are some fifteen years old. It will take a period of use to evaluate the differences, but this will be a treat. Now if we only had the second edition on compact disc: this is not planned until around 1992.

Roget's II: The New Thesaurus (Guide AD109) has appeared in an expanded edition (Boston, Houghton Mifflin, [1988]. $1,135$ p. $\$ 12.95)$ with the addition of nearsynonyms, antonyms, and nearantonyms to many of the words.

Gale continues publishing its series of directories. The Directory of Directories (Guide CH256) is now Directories In Print (Detroit, Gale, 1989. \$195) with the sixth edition, currently covering over 10,000 publications. The index also includes references to entries in the International Directories in Print (Detroit, Gale, 1988. \$175).

The ninth edition of the Publisher's Directory (Detroit, Gale, 1989, \$275. Guide AD355) is now in one volume in a threecolumn format. What is most useful, however, is the inclusion of entries from the Literary Market Place (Guide AA353) instead of cross-references as in previous editions.

The Personal Name Index to The New York Times Index, 1975-1984 Supplement compiled by Bryan A. and Valerie R. Falk (Verdi, Nevada, Roxbury Data Interface, [1988], for earlier years of coverage see Guide AF79) concludes with volume 4, $\mathrm{R}-\mathrm{Z}$. The editors note that the volume includes errata entries from 1851-1974 although a check of four pages of text and the beginning and end pages locates no errata.

Just arrived is the seventeenth edition of American Men and Women of Science, 1989-90, subtitled "A Biographical Directory of Today's Leaders in Physical, Biological and Related Sciences"' (New York,
Bowker, 1989. 8v. \$650; previous editions Guide EA221). The dictionary covers over 3,800 scientists "who have made significant contributions in their field" (Pref.) and provides a discipline index. Now maybe Bowker can get down to updating the social sciences volume, which is still in the thirteenth edition (Guide CA75).

The Bicentennial Edition of the Biographical Directory of the United States Congress, 1774-1989 (Washington, GPO, 1989. 2,104p. Senate doc. 100-34) includes some 11,000 men and women who were in Congress at any time from 1774 to June 30 , 1988. The previous volume (Guide CJ140) covered to 1971. A new feature is the reference to scholarly biographical dictionaries such as the Dictionary of American Biography and to books and articles for longer accounts.

Publications of the United States Congress seem difficult to identify and locate, though, of course, important. Two revised editions of aids for researching this material have been issued. In Congress and Lawmaking: Researching the Legislative Process (Santa Barbara, Calif., ABC-Clio; Oxford, Eng., Clio Pr., [1989]. 306p. \$35; 1st ed. 1979, Guide CJ132), Robert Goehlert and Fenton S. Martin have revised, expanded, and updated the text and the bibliographies. Very useful is a new detailed section in Chapter One on how a bill passes through Congress and on how to compile a legislative history. The other new edition is Congressional Publications and Proceedings: Research on Legislation, Budgets and Treaties (Englewood, Colo., Libraries Unlimited, 1988. 299p. \$27.50; first edition 1983 entitled Congressional Publications). This volume, too, is extensively updated and revised and adds Appendix B: Legislative Information Sources identifying congressional, and other federal and nonfederal publications.

The catalog of the Library of Harvard's Peabody Museum of Archaeology and Ethnology was published in 1963 with four supplements (Guide CE12). Now named the Tozzer Library at Harvard, this catalog is issued in a second edition cumulating earlier entries and, of course, adding newer acquisitions through June 1986 (Boston, G.K. Hall, 1989. 1,116 fiche. 
$\$ 6,000)$. The citations are divided between author/title and subject as in the older edition. Changes in the headings can confuse readers, e.g., Mexico-Archaeology[name of site] is no longer used. To update this catalog the same publisher is issuing an annual Bibliographic Guide to Anthropology and Archaeology, 1987- (Boston, G.K. Hall, 1988. \$165) for materials cataloged by the Tozzer Library: books, serials, manuscripts, microforms, maps and video recordings. A reminder: journal articles are cited in the Tozzer's Anthropological Literature from July 1984 on (Guide CE28).

The Handbook of American Popular Literature (Westport, Conn.: Greenwood [1988]. 408p. \$55) edited by M. Thomas Inge is an updating and revision of ten of the chapters of the Handbook of American Popular Culture (Guide CF90), e.g., children's literature, detective and mystery novels, etc., with the addition of four chapters, big little books, comic books, popular history and biography, and young adult fiction.

The Twentieth Century is now covered by European Writers (New York, Scribner, [1989], 2v. \$150). Volumes 8 and 9 of the series, they feature Freud to Valery, and Pio Baroja to Kafka. And in another series, A Library of Literary Criticism, a part of Europe is also covered by Modern Spanish and Portuguese Literatures (New York, Ungar, 1988. 615p. \$75). Compiled by Marshall J. Schneider and Irwin Stern it presents an overview of selections from critical opinion up to around 1984 for authors of Spain and Portugal writing in Spanish, Catalan, Galician, and Portuguese.

Robert E. Bell's Place-Names in Classical Mythology: Greece (Santa Barbara, Calif., ABC-Clio, [1989]. 350p. \$50) is a companion to his earlier Dictionary of Classical Mythology: Symbols, Attributes and Associations (Guide CF23). This time Bell has identified about 1,000 places and given a few sentences for each, locating the site and adding its mythological context. Ancient authors in the Loeb Classical Editions are cited wherever appropriate.

$\mathrm{ABC}-\mathrm{Clio}$ has produced another compilation of entries from their databases: Historical Abstracts and America: History and
Life, this time for Bibliographies in History (Santa Barbara, Calif., ABC-Clio, [1989]. 2v. \$137.50). Subtitled, An Index to Bibliographies in History Journals and Dissertations Covering the United States and Canada, the set includes any citation which has been indexed by the term "Bibliography" or "Bibliographies." The beginning date of coverage appears to be 1970 with a few citations from as early as 1965.

Paolo Enrico Coletta has issued a revised edition of his 1981 Bibliography of American Naval History (Guide DB23), now called A Selected and Annotated Bibliography of American Naval History (Lanham, Md., University Pr. of America, [1988]. 523p. $\$ 39.50)$. Over 60 percent of the entries have been dropped to make room for more recent ones and the total number of citations comes in at 4,677 entries. The subject index has been expanded. However "Zimmermann Telegram" has been lost and references for specific ships are now in the Author Index. Appendixes list secretaries of the Navy and chiefs of naval operations.

Chris Cook and John Stevenson continue their series of handbooks by compiling British Historical Facts, 1688-1760 ([London], Macmillan, [1988]. 252p. £35). This volume follows their English Historical Facts 1603-1688 (Guide DC303) and precedes British Historical Facts 1760-1830 (Guide DC304).

The Spanish Civil War continues to fascinate and this year we have Band 2 of Der Spanische Bürgerkrieg: Literatur und Bibliographie by Klaus-Jörg Ruhl (München, Bernard \& Graefe, 1988. 225p. 56DM; Scriften der Bibliothek für Zeitgeschichte N.F. Bd. 26; Guide DB484 for v.1). This volume covers political, economic and military topics and adds a supplement of publications omitted inadvertently or too new for inclusion in volume one.

The Canadian Encyclopedia second edition, edited by James H. Marsh (Edmonton, Hurtig Publishers, [1988]. 4v. (2,736p.) \$175. 1st ed. 1985) has been updated, of course, but also new articles have been added, the index expanded, and the number of tables, graphs, charts, etc., also increased. All of the articles are 
signed, some have bibliographic references, and many of these have been updated to 1983-1986. A supplementary volume is under discussion.

The series of Patricia Kennedy Grimsted, Archives and Manuscript Repositories of the USSR (Guide AB155-AB156) continues with Ukraine and Moldavia (Princeton, N.J., Princeton Univ. Pr., [1988]. v.1, 1,107p. \$125). Part I is a bibliography of finding aids for the area and for specific institutions, while Part II will present a historical survey of the archives and their practices. Like others in the series the volume is keyed to a microfilm series produced by Interdok of Zug, Switzerland.

Yvette Scheven has compiled five-year lists of bibliographies for Africanists beginning with 1970 (Guide DD83-DD84). Now a cumulation and update has appeared, Bibliographies for African Studies 1970-1986 (London, New York, Zell, 1988. 615 p. £58) thus making it much easier to use. 


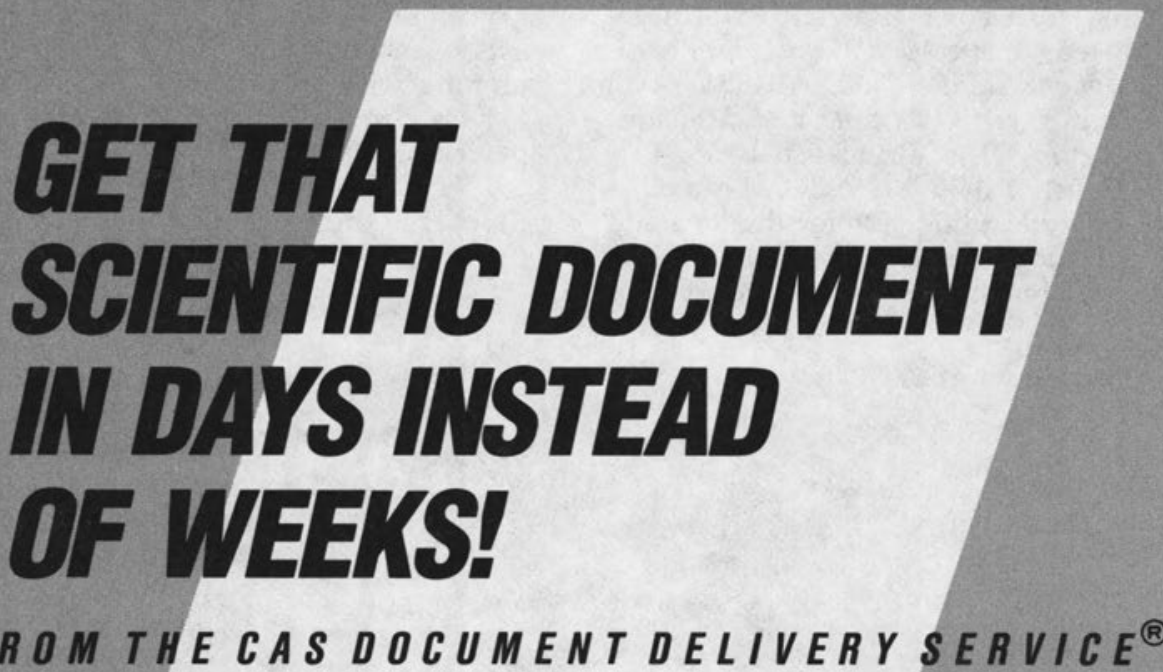

FROM THE CAS DOCUMENT DELIVERYSERVICE

When you must have an original document, go to the Chemical Abstracts Service ${ }^{\circledR}$ Document Delivery Service. CAS DDS provides photocopies or loans of single documents from CAS's scientific collection, including serials, patents, conference proceedings, symposia. You can order
- Soviet documents published since 1970

- Articles from any issue of an American Chemical Society journal Other documents published since 1975 If you need that document immediately, order NOW. Most orders are on their way within 24 hours.

$\square$ Yesl I'd like more information about CAS Document Delivery Service.

$\square$ Please send me my FREE CAS DDS Directory of Publications.

Name

Organization

Address

Phone
Mail to:

Chemical Abstracts Service ${ }^{\circledR}$

Marketing, Dept. 34089

2540 Olentangy River Road

P.0. Box 3012

Columbus, Ohio 43210

Phone:

Toll Free 800-848-6538, ext. 3670

or 614-447-3670 